\title{
Coffee Cultivation in Kerala: Some Economic Aspects
}

\author{
N Karunakaran ${ }^{*}$
}

\section{Abstract}

Coffee production in India is mostly done in Karnataka, Kerala and Tamilnadu. It is one of the important commercial crops of Keralaand is the main source of income and employment to the people of three districts in Kerala. Coffee cultivation is not an easy businessandis adversely affected by various factors at present. Small coffee growers fail to acquiretechnological improvement to compensate labour scarcity and climate change and have limited access to technologies promoted by the Coffee Board of India due to high cost and mode of payment of subsidies. This studyreveals that problems like scarcity of labour, pests and diseases, thehigh cost of production, low price for coffee, marketing difficulties and unusual climate changes often hurt coffee cultivators. However, the schemes and programmes ofthe coffee board benefited the growers. Theanalysis of the profitability of the crop shows that coffee cultivation is profitable in Kerala.

Keywords: Coffee cultivation, Coffee board, Profitability, Kerala

\section{Introduction}

Coffee is grown mainly in the agrarian countries of the tropical and sub-tropical regions of the world. There are 70 major commercial coffee producing countries mostly in South America, Asia and Africa (Harriset al., 2013). Top coffee producing countries include

\footnotetext{
*EKNM Government College, Elerithattu, Kerala, India. narankarun@gmail.com
} 
Brazil, Columbia, Indonesia, India, Costa-Rica, Guatemala, Ivory Coast, Kenya, Tanzania, Uganda, Ethiopia, Zimbabwe and Vietnam. Brazil is the world-leader in the production of coffee, followed by Vietnam. India holds thesixth positionin coffee production (Karunakaran and Vineesh, 2015).

In India, coffee is majorly produced in the southernstates of IndiaKarnataka contributing 71percent, Kerala 21percent and Tamil Nadu 5percent of production. Coffee producing regions are of two types: traditional and non-traditional. While states like Karnataka, Kerala and Tamil Nadu are considered as traditional coffee producers, areas of Andhra Pradesh and Orissa in the eastern coast and states of Assam, Manipur, Meghalaya, Mizoram, Tripura, Nagaland and Arunachal Pradesh of thenortheasternpart are classified as non-traditional coffee producers (Karunakaran, 2015). The two well-known species of coffee grown in the country are Arabica and Robusta. Arabica is the most common variety of coffee grown in the country (Gholam and Indira, 2013). Indian coffee is the finest grown in the shade than direct sunlight anywhere in the world. More than 250000 coffee growers are in India, and 98percent of them are small farmers. About 80percent of the production is exported to Germany, Russia, Spain, Belgium, Slovenia, United States, Japan, Greece, Netherlands, France and Italy (Prasad, 2010).

Coffee, a popular crop in Kerala, is not an easy business and, at present, it is adversely affected by various factors. A sharp decline in the price of produce, increasing input cost, scarcity of workers, lack of support from the Coffee Board and increasing price of fertilizers are the major concerns of the farmers. Small coffee growers can't stock coffee for a long time and are hence forced to sell theirproduce, even if they only get a low price in the market, because of their financial needs (Karthigaiselvan and Maran, 2013). Traders exploit this opportunity and make aprofit. Labour scarcity is another such severe problem; in the case of coffee, it usually requires women labourers. Small coffee growers fail to acquire technological improvement to compensate the labour scarcity and climate change. They are also affected by their limited access to new technology promoted by the Coffee Board of India and mode of payment of subsidies. Naturally, there are certain determinants 
in the cultivation of this crop. Any change in its cultivation either in terms of area, production or productivity would seriously affect the weaker sections of the agricultural population. The cost of production and returns are very important for this crop (Pushpa and Madhava, 2011). Hence in this paper, an attempt is made to examine some economic aspects such as area, production, productivity, problems and prospects, cost of production and profitability of coffee cultivation in Kerala.

\section{Methodology and Materials}

The methodology adopted in this study is to analyse the data collected from secondary and primary sources. Primary data were collected using questionnaire and informal discussions with select coffee growers from Wayanad district, Kerala. Secondary data werecollected from the office of the Coffee Boardof India and the Directorate of Economics and Statistics, Ministry of Agriculture and Farmers Welfare, Government of India.Profitability is analysedusing theNet PresentValue (NPV) and Benefit Cost Ratio (BCR).

(i) Net Present Value (NPV): The Net Present Value (NPV) is the current value of net benefitsof all projects. Net benefits are simply the sum of benefits minus costs. The sum is discounted at the discount rate. Using this method, if the project has an NPV greater than zero, it appears to be a good venture (If the calculated NPV > 0 , the project is profitable).The NPV is calculatedusing the formulae:

$$
N P V=\sum_{t=1}^{T} \frac{\left(\text { Benefit }_{t}-\text { Cost }_{t}\right)}{(1+r)^{t}}
$$

(ii) Benefit-CostRatio (BCR): The Benefit-Cost Ratio (BCR) is calculated as the NPV of benefits divided by the NPV of costs:

$$
B C R=\frac{\sum_{r=1}^{r} \frac{B_{t}}{(1+r)^{t}}}{\sum_{r=1}^{r} \frac{C_{t}}{(1+r)^{t}}}
$$


(Where, $B_{t}$ is the benefit in time $t$ and $C_{t}$ is the cost in time $t$ ). If the calculated $B C R>1$, the project is profitableand is a good activity for acceptance.

Table 1 Share of major countries in coffee production

\begin{tabular}{clc}
\hline Sl. No. & Countries & Share in global production (in percent) \\
\hline 1 & Brazil & 35.0 \\
2 & Vietnam & 15.2 \\
3 & Indonesia & 8.8 \\
4 & Colombia & 7.1 \\
5 & Ethiopia & 4.4 \\
6 & India & 3.7 \\
7 & Honduras & 3.1 \\
8 & Peru & 3.1 \\
9 & Mexico & 3.0 \\
10 & Guatemala & 2.6 \\
\hline
\end{tabular}

Source: Karunakaran and Vineesh(2015), "Problems and prospects of small coffee growers of Wayanad district, Kerala", Asian Economic Review, 57 (3): 115.

\section{Analysis and Discussion}

Coffee production in the global context: Coffee as a commercial crop is grown in several countries of South America, Asia and Africa. Table 1 shows the percentage share of important countries in the world in total coffee production.The important verities of coffee produced in the world are Arabica and Robusta.

Area and production of coffee in India and Kerala: Coffee occupies a place of pride among plantation crops in India. The area under coffee is around 4.35 lakh hectare; of which Arabica accounts for 2.21 lakh hectare and Robusta is cultivated in the rest (Table 2). The annual average production is around 3.48 lakh million tonne. Annually, Coffee contributes nearly Rs 4600 crores of foreign exchange to the nation. The production area of coffee is distributed in a total of 2.91 lakh holdings of which only 2658 belongs to larger grower sector (Karunakaran, 2015). 
N Karunakaran Coffee Cultivation in Kerala: Some Economic Aspects

Table 2 Area and production of coffee in India

\begin{tabular}{|c|c|c|c|c|c|c|c|c|c|c|}
\hline \multirow{2}{*}{ Year } & \multicolumn{5}{|c|}{ Area (in hectare) } & \multicolumn{5}{|c|}{ Production (in million tonne) } \\
\hline & Arabica & $\%$ & Robusta & $\%$ & Total & Arabica & $\%$ & Robusta & $\%$ & Total \\
\hline $\begin{array}{c}1950- \\
51\end{array}$ & 67613 & 73 & 24910 & 27 & 92523 & 15511 & 82 & 3382 & 18 & 18893 \\
\hline $\begin{array}{c}1960- \\
61\end{array}$ & 70650 & 59 & 49670 & 41 & 120320 & 39526 & 58 & 28643 & 42 & 68169 \\
\hline $\begin{array}{c}1970- \\
71\end{array}$ & 80433 & 59 & 55030 & 41 & 135463 & 58348 & 53 & 51883 & 47 & 110231 \\
\hline $\begin{array}{c}1980- \\
81\end{array}$ & 109454 & 53 & 98815 & 47 & 208269 & 61262 & 52 & 57384 & 48 & 118646 \\
\hline $\begin{array}{c}1990- \\
91\end{array}$ & 127934 & 47 & 142887 & 53 & 270821 & 78311 & 46 & 91415 & 54 & 169726 \\
\hline $\begin{array}{c}2000- \\
01\end{array}$ & 167679 & 48 & 179037 & 52 & 346716 & 104400 & 35 & 196800 & 65 & 301200 \\
\hline $\begin{array}{c}2010- \\
11\end{array}$ & 197930 & 49 & 206715 & 51 & 404645 & 94140 & 32 & 207860 & 69 & 302000 \\
\hline $\begin{array}{c}2015- \\
16\end{array}$ & 221379 & 51 & 213057 & 49 & 434436 & 103500 & 30 & 244500 & 70 & 348000 \\
\hline
\end{tabular}

Source: $w w w . i n d i a c o f f e e . o r g$

As an agro-based rural activity, it is a source of employment for over one million people in cultivation, processing and trade sectors. Coffee cultivation is also instrumental in preserving the precious forest eco-system in traditional areas while in non-traditional areas it was introduced to check the shift in cultivation and prevent soil erosion. As a perennial crop, coffee is one of the main plantation cropsgrown in the southern states of India and the real backbone of coffee cultivation in India is the small growers (Shalima et al., 2008). There were 138 thousand registered cultivators in the country; among them, 98 percent were small growers who hold less than 10 hectares of land each and produce 35 percent of total output (Prapulla and Indira, 2014). 
Table 3 Area and production of coffee in India by states (2015-16)

\begin{tabular}{|c|c|c|c|c|c|c|c|}
\hline Items & $\begin{array}{c}\text { Karnatak } \\
\text { a }\end{array}$ & $\begin{array}{c}\text { Keral } \\
\mathrm{a}\end{array}$ & $\begin{array}{c}\text { Tamilnad } \\
\mathrm{u}\end{array}$ & $\begin{array}{l}\text { Total for } \\
\text { Tradition } \\
\text { al states }\end{array}$ & $\begin{array}{c}\text { Non } \\
\text { Tradition } \\
\text { al states }\end{array}$ & $\begin{array}{l}\text { North } \\
\text { Easter } \\
\mathrm{n} \\
\text { states }\end{array}$ & Total \\
\hline \multicolumn{8}{|c|}{ Area (in hectare) } \\
\hline $\begin{array}{c}\text { Arabic } \\
\text { a }\end{array}$ & 111225 & 4217 & 29062 & 144504 & 71280 & 5595 & 221379 \\
\hline$\%$ & 25.6 & 1.0 & 6.7 & 33.3 & 16.4 & 1.3 & 51.0 \\
\hline $\begin{array}{c}\text { Robust } \\
\mathrm{a}\end{array}$ & 124213 & 81284 & 5870 & 211367 & 267 & 1423 & 213057 \\
\hline$\%$ & 28.6 & 18.7 & 1.4 & 48.7 & 0.1 & 0.3 & 49.0 \\
\hline Total & 235438 & 85501 & 34932 & 355871 & 71547 & 7018 & 434436 \\
\hline$\%$ & 54.2 & 19.7 & 8.0 & 81.9 & 16.5 & 1.6 & 100 \\
\hline \multicolumn{8}{|c|}{ Production (in million tonne) } \\
\hline Arabica & 78650 & 2200 & 12810 & 93660 & 9750 & 90 & 103500 \\
\hline$\%$ & 22.6 & 0.6 & 3.7 & 26.9 & 2.8 & 0 & 29.7 \\
\hline $\begin{array}{c}\text { Robust } \\
\text { a }\end{array}$ & 172870 & 67030 & 4485 & 244385 & 50 & 65 & 244500 \\
\hline$\%$ & 49.7 & 19.3 & 1.3 & 70.2 & 0 & 0 & 70.3 \\
\hline Total & 251520 & 69230 & 17295 & 338045 & 9800 & 155 & $\begin{array}{c}34800 \\
0\end{array}$ \\
\hline$\%$ & 72.3 & 19.9 & 5.0 & 97.1 & 2.8 & 0 & 100 \\
\hline
\end{tabular}

Source: www.indiacoffee.org

Kerala is the second largest producer of coffee in India. As on 201516, coffee is grownin an area of 85501hectares comprising of 81284hectares of Robusta and 4217hectares of Arabica (Table 3). A major percentage of coffee cultivation in Kerala is donein Wayanad and a considerable area is in Palakkad and Idukki districts (Table 4). The average annual production of coffee is 69230 million tonnes comprising of 67030 milliontonnes of Robusta and 2200 million tonnes of Arabica. The average productivity of Robusta holdings is $850 \mathrm{~kg}$ per hectare and that of Arabica is $420 \mathrm{~kg}$ per hectare (Karunakaran, 2015). 
N Karunakaran Coffee Cultivation in Kerala: Some Economic Aspects

Table 4 Change in the Cultivated area of Coffee in Kerala (Percentage of Total Cropped Area)

\begin{tabular}{cccccccc}
\hline Sl. & \multirow{2}{*}{ Districts } & $1960-$ & $1970-$ & $1980-$ & $1990-$ & $2000-$ & $2015-$ \\
No. & & 61 & 71 & 81 & 91 & 01 & 16 \\
\hline 1 & Idukki & - & - & 3.0 & 5.6 & 4.0 & 3.9 \\
2 & Palakkad & 0.6 & 0.9 & 0.7 & 0.7 & 1.5 & 1.4 \\
3 & Wayanad & - & - & - & 37.6 & 32.3 & 31.4 \\
4 & State & 0.7 & 1.1 & 2.0 & 2.5 & 2.8 & 3.2 \\
\hline
\end{tabular}

Source: Computed from Economic Review (various issues), State Planning Board, Govt. of Kerala, Thiruvananthapuram

Coffee cultivation and profitability: The problems of coffee growers and profitability are analysed by studying BCR and NPVand are shown in table 5.The time element of costs and returns were worked out. The discount rate is used,and it variesfrom 8 to 12 percentage; these measures were calculated separately for two discount rates, viz., 8.75 and 9 percentage. Table 5results of NPV at 8.75 and 9 percentage were positive and quite high indicating profitability of this cultivation. The BCRat 9 percentage of discount rate ranged from 1.141 percentto 1.341 percent. Even at a low rate of discount of 8.75 percentage, it ranged from 1.101 percentto 1.302 percent. In all size groups, it was greater than unity, showing theprofitabilityofcultivation.

Table 5 Coffee Cultivation and profitability in Kerala

\begin{tabular}{ccccc}
\hline \multirow{2}{*}{ Particulars } & \multicolumn{3}{c}{ Size of farm } \\
& & Small & Medium & Large \\
\hline NPV (in Rs) & $9 \%$ & 577664 (II) & $594590(\mathrm{I})$ & 555744 (III) \\
& $8.75 \%$ & 571069 (II) & $586480(\mathrm{I})$ & $554292(\mathrm{III})$ \\
BCR(in \%) & $9 \%$ & $1.232(\mathrm{II})$ & 1.341 (I) & 1.141 (III) \\
& $8.75 \%$ & 1.231 (II) & $1.302(\mathrm{I})$ & 1.101 (III) \\
\hline
\end{tabular}

Figures in bracket indicate rank.

Labour shortage problem: From the study, it is revealed that there is a high shortage of labour in the coffee sector. Introduction of NREGA, diversification of labour to high wage sector, unsatisfactory attitudes of youth towards agriculture, low wage rates are the major reasons for this. From figure 1, themajority of the producers revealed that NREGA is the main reason for the shortage of labour. Migration of labour from agriculture sector to 
other sectors, theunsatisfactory attitude of youth towards agriculture are other reasonsfor this shortage.

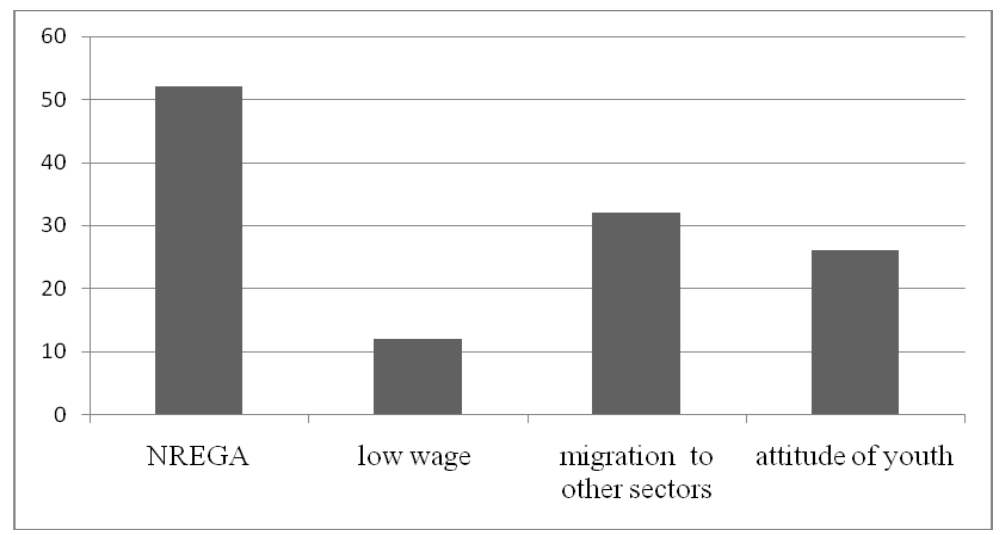

Fig 1 Reasons for Shortage of Labour

Assistance from Coffee Board and its effectiveness: The important assistance from the board includes research, financial assistance to growers, programmes to labourers and saleof asurplus pool of unsold coffee. Among these, financial assistance to small coffee growers andsafeguardingthe working conditions of labourers are very important. This assistance also includes various subsidies to farmers, providing equipment andhigh yielding seeds and plants, irrigation promotion, insurance protection (rainfall insurance scheme for coffee), training to farmers and scholarship to students of coffee growers and workers. Table 6 shows that 43 percent of the farmers received support from the Board. Among this, 37 percent have subsidies, 27 percent received equipment, 18 percent benefited support for irrigation, 22percent of farmers received support for high yielding coffee seeds and plants, and 23 percent received various scholarships. 
N Karunakaran Coffee Cultivation in Kerala: Some Economic Aspects

Table 6 Assistance from Coffee Board of India

\begin{tabular}{clc}
\hline Sl. No. & \multicolumn{1}{c}{ Items } & Percent of farmers benefited \\
\hline 1 & Subsidy & 37 \\
2 & Equipment & 27 \\
3 & Irrigation & 18 \\
4 & Seed and plant & 22 \\
5 & Insurance & 0 \\
6 & Training & 5 \\
7 & Scholarship & 23 \\
\hline
\end{tabular}

Source: Primary data

Duration of the last service received by farmers is important to understand how effective the board influenced coffee cultivation.Among thefarmers who received assistance, 23 percent of the farmers received it in the last year, 12 percent within 1 to 2 years and 15 percent between 2 to 3 years. Majority of the farmers ( 31 percent) benefited between 3 to 5 years and 19 percent received the service of theCoffeeBoard before five years (Table 7).

Table 7 Duration of the last service received from Coffee Board

\begin{tabular}{clc}
\hline Sl. No. & \multicolumn{1}{c}{ Time } & Percent of farmers received \\
\hline 1 & Within one year & 23 \\
2 & Between 1 and2 years & 12 \\
3 & Between 2 and3 years & 15 \\
4 & Between 3 and5 years & 31 \\
5 & Before 5 years & 19 \\
& Total & 100 \\
\hline
\end{tabular}

Source: Primary data

The effectiveness of each service to farmers is presented in Table 8 and indicates that many services provided by theCoffeeBoard has benefited only a very limited number of farmers. Among these, subsidies, equipment for mechanization and scholarship for students are more effective. The other schemes like support for irrigation, high yielding coffee seeds and plants are helpful only to less than 20 percent of farmers. 
Table 8 Effectiveness of the services of Coffee Board

\begin{tabular}{clccc}
\hline \multicolumn{2}{c}{ Services } & $\begin{array}{c}\text { Highly } \\
\text { effective }\end{array}$ & $\begin{array}{c}\text { Level of effectiveness } \\
\text { Moderately } \\
\text { effective }\end{array}$ & $\begin{array}{c}\text { Low } \\
\text { effective }\end{array}$ \\
\hline Subsidy & Number & 19 & 3 & 38 \\
& Percentage & 32 & 5 & 63 \\
Equipment & Number & 12 & 8 & 40 \\
& Percentage & 20 & 13 & 67 \\
Irrigation & Number & 8 & 3 & 49 \\
& Percentage & 13 & 5 & 82 \\
Seed or & Number & 11 & 7 & 42 \\
plant & Percentage & 18 & 12 & 70 \\
Insurance & Number & 0 & 0 & 60 \\
& Percentage & 0 & 0 & 100 \\
Training & Number & 3 & 4 & 53 \\
Scholarship & Percentage & 5 & 7 & 88 \\
& Number & 14 & 8 & 38 \\
\hline Soumbentage & 23 & 13 & 63 \\
\hline
\end{tabular}

Source: Primary data

Figure2presents the satisfaction level of beneficiariesand shows that 37 percent are satisfied and the rest 63 percent not satisfied with the functioning of the Coffee Board. This is because the farmers are often not aware of the activities, benefits are limitedand procedures to receive them are complicated.

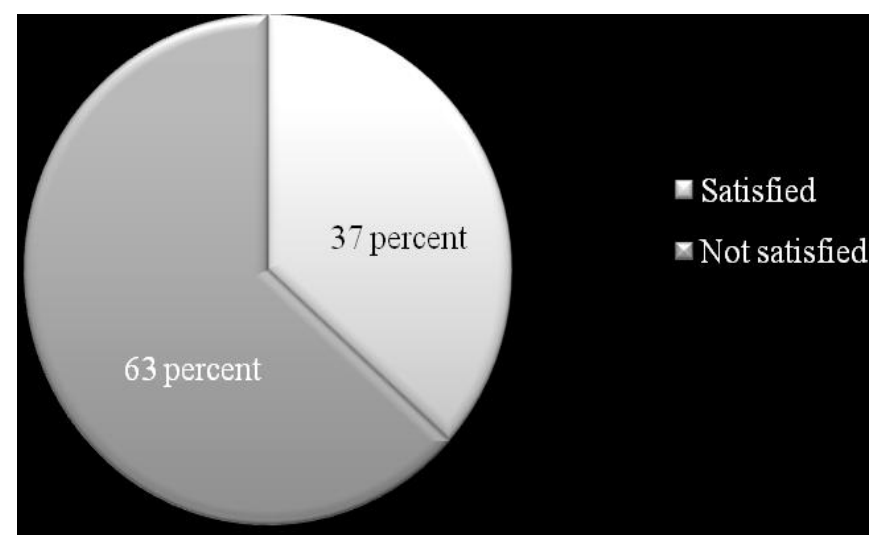

Fig 2 Satisfaction of farmers about the functioning of the Coffee Board 


\section{Conclusion}

Indian coffee is said to be the finest coffee grown in the shade rather than direct sunlight anywhere in the world. Coffee production is mostly dominated in the hill tracts of south Indian states, with the state of Karnataka, Kerala and Tamilnadu. Kerala has the second position in the production of coffee which accounts 23 percent of the country's production. It is one important commercial crop and is the main source of income and employment to the people of Kerala, particularly in the three districts covered in the study.

Coffee cultivation is not an easy business and various factors are adversely affecting it at present. A sharp decline in the price of produce, increasing input cost, scarcity of workers, lack of support from the coffee board and increasing price of fertilizers are the major concern of the farmers.

Coffee Board of India has played an important role in promoting coffee cultivation. Financial support such as loan and subsidies are given to the farmers for preparing the coffee plantations, mechanization of the coffee gardens and irrigation. It also acts as an adviser, facilitator and the sole marketing channel for coffee. By the intervention of private market, the Board has reduced its functions to advice and support through subsidies and research. It has also reduced the functions of its marketing wing and thereby the financial loans provided to the farmers. At present, subsidies are the major tool used to promote coffee cultivation.

Even though the Coffee Board is providing various services, many growers remain out of its benefits. The analysis revealed that subsidies, equipment for mechanization and the scholarships for students are said to be more effective; other schemes like support for irrigation, provision of high yielding coffee seeds and plants are effective only to 20 percent of farmers. This is because of the unawareness regarding the functioning of the board. The system of pooling the resources of the Coffee Board to support small coffee growers to get better price should be restartedand the mode of payment of subsidies may be changed.The number of beneficiaries may be increased in proportion to the needy so as to make it more inclusive. 


\section{References}

Darvishi, G. A.and Indira, M. (2013).An Analysisof Changing Pattern in Area, Production and Productivity of Coffee and Tea in India.International Journal of Marketing Financial Services and Management Research, 2(9),46-60.

Harris, E., Abdul-Aziz, A. R., \& Avuglah, R. K. (2012). Modeling annual Coffee production in Ghana using ARIMA time series Model.International Journal of Business and Social Research, 2(7), 175-186.

Karthigaiselvan and Maran, B. (2013).Production and marketing of coffee in Tamilnadu. Shan lax International Journal of Commerce, 1(3), 1-4.

Karunakaran, N. (2015). Coffee cultivation: Is it profitable in Kerala.Southern Economist, 54(7), 13-16.

Karunakaran, N. and Vineesh, V. (2015).Problems and prospects of small coffee growers of Wayanad district, Kerala. Asian Economic Review, 57(3) 111-120.

Tiwari, K. P. (2010). Agricultural policy review for coffee promotion in Nepal.The Journal of Agriculture and Environment, 11 (1), 138-147.

Malladi, P. and Indira, M. (2014).Impact of trade liberalization on Indian coffee exports.International Journal of Advanced Research in Management and Social Sciences, 3(4), 27-42.

Murthy, P. S., \& Naidu, M. M. (2011).Improvement of Robusta Coffee Fermentation with Microbial Enzymes.European Journal of Applied sciences, 3(4), 130-139.

Devi, G. S., \& Kumar, K. A. (2008).Remote Sensing and GIS Application for Land Quality Assessment for Coffee Growing Areas of Karnataka.Journal of the Indian Society of Remote sensing, 36(1), 89-97. 